\title{
PENGEMBANGAN KURIKULUM BERBASIS ADIWIYATA DI SEKOLAH MENENGAH KEJURUAN
}

\author{
Moh. Arief Hariyanto*
}

\begin{abstract}
Abstrak: Pada masa ini, peran strategis dalam pengembangan kurikulum di dunia pendidikan adalah menciptakan sekolah yang berkualitas dan berkuantitas. Salah satu program adiwiyata dalam mengembangkan kurikulum pada dasarnya adalah sekolah yang memiliki pengaruh sangat besar terhadap kelestarian lingkungan dan juga siswa yang akan mendapatkan pengetahuan tentang lingkungan. Kompetensi pendidik dan staf kependidikan memiliki peran aktif dalam mengembangkan pembelajaran yang terintegrasi dengan lingkungan. Kegiatan pembelajaran yang dilakukan oleh siswa adalah menghasilkan karya nyata yang berkaitan dengan lingkungan dan mengkomunikasikan hasil belajar melalui berbagai media. Implikasi dari kurikulum berbasis adiwiyata adalah keterlibatan pemangku kepentingan, fasilitas dan lingkungan sekolah sekitarnya yang semuanya merupakan faktor pendukung untuk program adiwiyata. Sedangkan faktor penghambat termasuk dana terbatas, sarana dan prasarana, sikap dan perilaku warga sekolah, pola pikir guru dan wali murid.
\end{abstract}

Kata kunci: Kurikulum, Strategis, Adiwiyata

\section{Pendahuluan}

7 ersoalan pendidikan di Indonesia begitu komplek. Berbagai problematika muncul tidak hanya dalam permasalahan L konsep pendidikan, peraturan, dan anggaran saja, namun persoalan pelaksanaan pendidikan dari berbagai sistem di Indonesia juga turut serta menambah kompleknya problematika pendidikan di

* Program Pascasarjana Universitas Nurul Jadid Paiton Probolinggo, serta sebagai tenaga pendidik di SMK Nurul Jadid di bawah naungan Yayasan Pondok Pesantren Paiton Probolinggo. Email: ariefhariyanto23@gmail.com 
Indonesia (Afifah, 2017: 41). Hal ini merupakan permasalahan yang perlu diperbaiki bersama baik tenaga pendidik maupun tenaga kependidikan.

Penyelenggaraan pendidikan di Indonesia memiliki harapan agar mampu mewujudkan proses perkembangan kualitas pribadi siswa sebagai generasi penerus bangsa di masa yang akan datang. Usaha sadar dan terencana dalam mewujudkan suasana belajar yang kondusif untuk proses pembelajaran, maka peserta didik secara aktif akan mengembangkan potensi dirinya secara pribadi dengan aktif untuk menciptakan da mewujudkan kekuatan spiritual keagamaan, pengendalian diri, kepribadian, kecerdasan, akhlak mulia, serta keterampilan yang diperlukan dirinya, masyarakat, bangsa dan Negara sehingga dapat diyakini akan menjadi faktor penentuan bagi tumbuh kembangnya bangsa dan negara Indonesia saat ini berdasarkan pancasila dan UUD 1945 yang berakar pada nilai-nilai agama, kebudayaan nasional Indonesia dan tanggap terhadap tuntutan perubahan zaman.

Salah satu faktor dalam persoalan di dunia pendidikan saat ini adalah tantangan dan peluang tersendiri bagi dunia pendidikan di negeri ini, khususnya pendidikan tinggi dalam mewujudkan model pendidikan masa depan (Purwantiningsih, 2018: 31, khususnya di negara kita yang masih kita sadarai sangat menonjol adalah adanya perubahan kurikulum yang terus berubah sehingga membebani anak dalam mengembangkan ilmu pengetahuan yang benar-benar diimplementasikan di sekolah. Dengan adanya perubahan tersebut merupakan keinginan kurikulum. Salah satu faktor utama keberhasilan dalam proses pendidikan ialah menjadikan kurikulum sebagai petunjuk dan arah untuk keberhasilan pendidikan. Kurikulum menjadi penuntun (guide), para pengampu pelajaran atau pelaksana pendidikan pendidik, tenaga kependidikan adalah untuk dapat mengembangkan kreativitas dan kemampuannya dalam mengembangkan semua materi dan perangkat pembelajaran. Jadi, pendidik dan tenaga kependidikan dikatakan baik apabila mampu melaksanakan dan memahami kurikulum untuk 
diimplementasikan dalam proses kegiatan pembelajaran (Machali, 2014: 81).

Adanya suatu perubahan kurikulum yang terjadi tidak dapat dipungkiri dan dapat mengarah pada suatu perubahan atau perbaikan sistem pendidikan (Imam, 2018: 1-21). Dengan perubahan tersebut kemudian dilakukan karena masih dianggap belum relevan atau tidak mengarah dengan apa yang menjadi harapan. Oleh karena itu perlu revitalisasi atau perubahan pengembangan kurikulum. Beberapa usaha tersebut akan dapat dilakukan demi terciptakan generasi-generasi anak penerus bangsa dengan memiliki karakter, memahami jati diri bangsa dan menjadikan generasi yang unggul disemua bidan dan mampu memiliki daya saing di dunia internasional dimasa mendatang.

Lingkungan (environment) sebagai media pendidikan merupakan factor kondisional yang memengaruhi tingkah laku individu dan merupakan faktor belajar yang penting (Baharun, 2017: 240. Melihat kutipan tersebut kita kaitkan dengan pengembangan Kurikulum yang memiliki sifat dinamis dikarenakan kurikulum selalu berubah dengan menyesuaikan perkembangan masa kini dan tantangan zaman. Lingkungan memiliki daya dukung yang sangat memengaruhi prilaku, semakin maju peradaban suatu bangsa, maka semakin berat pula tantangan yang dihadapinya. Saat ini di dunia Internasional persaingan ilmu pengatahuan sangatlah gencar dilakukan, sehingga kita sebagai warga Indonesia juga dituntus dapat bersaing secara umum untuk meningkatkan martabat bangsa. Dapat disimpulkan bahwa dalam menghadapi semua tantangan yang akan dihadapi di dunia pendidikan kita saat ini bagaimana kemudian ketegasan pemerintah dalam mengembangkan kurikulum kita dapat diimplentasikan dengan baik, sehingga sangat dibutuhkan dalam memperbaiki kinerja pendidikan kita untuk bisa meningkatkan daya saing di negera tetangga misalnya malaysia, singapura dan tidak menutup kemungkinan di negara maju dunia. 


\section{Kurikulum}

Kurikulum "curriculum" yaitu curir yang artinya berlari dan currere yang berarti tempat berpacu. Dalam bahasa Yunani, Latin "curriculum" yang semula adalah a running course, or race course, especially a chariot race course, sedangkan menurut bahasa Prancis "courier" artinya "to run, berlari". Istilah itulah yang digunakan untuk sejumlah "courses" atau mata pelajaran yang harus tuntas untuk mencapai suatu ijasah atau gelar (Machali, 2014: 73). Di dalam Kamus Besar Bahasa Indonesia (KBBI) kurikulum yaitu suatu perangkat mata pelajaran yang disampaikan maupun diajarkan pada lembaga pendidikan.

Kurikulum adalah suatu perangkat dalam sebuah pengalaman belajar yang akan diperoleh peserta didik selama menjalankan proses pendidikan. Kurikulum dirancang untuk dapat mencapai tujuan yang diharapkan Fujiawati, 2016: 16-18). Jadi, kurikulum sangatlah penting dalam proses pendidikan agar proses pendidikan berjalan dengan baik dan sesuai harapan. Faktor kemampuan yang dimiliki seorang pendidikan atau guru adalah untuk mencapai keberhasilan dalam mengimpelentasikan kurikulum. Artinya guru merupakan orang yang memiliki tanggung jawab dalam upaya menciptakan suasana efekif dari segala sesuatu yang jelas tertuang dalam kurikulum.

Menurut Harold B. Alberty dalam Asep Herry Hernawan, Rudi Susilana \& dkk., kurikulum adalah merupakan segala bentuk kegiatan dalam proses pendidikan di bawah pantauan tanggung jawab sekolah yang diberikan kepada siswa. Sedangkan menurut Saylor, Alexander \& Lewis dalam Asep Herry Hernawan, Rudi Susilana \& dkk. Beranggapan bahwa kurikulum merupakan usaha untuk mengupayakan suatu lembaga atau sekolah dalam memberikan pengaruh terhadap siswa supaya belajar, baik dalam ruangan kelas, di halaman sekolah, maupun di luar sekolah". Kemudian dapat disimpulkan bahwa kurikulum merupakan salah satu cara dalam mencapai tujuan pendidikan secara umum, serta sekaligus digunakan dalam pedoman pelaksanaan proses belajar mengajar pada berbagai jenjang sekolah. Dapat 
disimpulkan bahwa kurikulum merupakan suatu sistem pembelajaran dan usaha terencana yang terorganisir untuk menciptakan suatu pengalaman belajar yang baik terhadap siswa dibawah pantauwan dan tanggung jawab sekolah atau lembaga pendidikan untuk mencapai tujuan pendidikan. Jadi, secara umum pengertian kurikulum bukan hanya berupa muatan mata pelajaran atau dilaksanakan dalam bentuk kegiatan-kegiatan belajar siswa saja melaikan berupa hal yang mempengaruhi terhadap pembentukan karakter pribadi anak sesuai dengan tujuan pendidikan yang diharapkan (Muali, 2017: 15-17).

\section{Kurikulum 2013}

Perubahan Kurikulum pada saat ini memiliki peran dan fungsi penting dan strategis walaupun bukan hanya salah satu faktor penentu utama dalam menentukan keberhasilan proses pendidikan, kurikulum menjadi petunjuk dan arah terhadap keberhasilan pendidikan. Kurikulum menjadi penuntun (guide) para pelaksana pendidikan pendidik, tenaga kependidikan untuk mengembangkan kreativitas dan kemampuannya dalam mengembangkan dan menjabarkan berbagai materi dan perangkat pembelajan. Oleh karena itu, pendidik dan tenaga kependidikan yang baik adalah yang mampu memahami kurikulum dan mengimplementasikannya pada proses pembelajaran (Machali, 2014: 81).

Menurut Muyoto, Kurikulum 2013 adalah hanyalah masalah pendekatan-pendekatan dalam proses pembelajaran. Realita selama ini, pendekatan-pendekatan yang telag digunakan adalah hanya materi. Jadi, penyampaian materi sebanyak mungkin yang diberikan kepada anak, sehingga mereka hanya menguasai materi itu secara maksimal tidak pada pengembangan keterampilan yang dimiliki. Bahkan untuk penguasaan materi, drilling sudah diberikan sejak dini awal pembelajaran, jauh sebelum siswa menghadapi ujian nasional. Dalam konsep pembelajaran seperti ini, tujuan pembelajaran yang aka dicapai lebih kepada aspek kognitif saja dengan menafikan aspek yang lain yaitu aspek psikomotrik dan afektif(Azis, 2016: 28-92). 
Sebenarnya dari ketiga aspek tersebut itu sudah mendapatkan penekanan terhadap kurikulum kita selama ini. Ketika pemberlakuan Kurikulum 2006, tiga aspek tersebut yaitu aspek kognitif, psikomotorik dan afektif (taksonomi Bloom tentang tujuan pendidikan), telah juga menjadi kompetensi integral yang harus dicapai. Pada saat pemberlakuan Kurikulum 2006, dengan melalui penekanan pendidikan karakter anak, aspek afektiflah yang seolah-olah terlupakan oleh para praktisi-praktisi pendidikan yang di gaungkan kembali.

Selama ini, berdasarkan pengalaman hal tersebut memiliki keharusan untuk didukung dengan didasari kebijakan oleh pemerintah dengan konsisten, yaitu dengan menggunakan sistem evaluasi sebagai tolak ukur pencapaian kemampuan dalam aspek kognitif, psikomotorik dan afektif secara seimbang. Tidak dapat dipungkiri bahwa ujian nasional harus dimoratorium atau dihentikan, sehingga penentu kelulusan siswa pada dan akhirnya yang diperoleh hanyalah transkrip dan nilai rapor per semester. Dimana nilai rapor merupakan hasil evaluasi (assesment) dalam seluruh proses kegiatan pembelajaran yang telah dilakukan dan mengandung tiga aspek secara penuh, begitu juga dalam proses pembelajaran.

\section{Prinsip Pengembangan Kurikulum 2013}

Kurikulum sangatlah berarti karena merupakan operasionalisasi dari tujuan yang dicita-citakan, dalam arti tujuan pendidikan tak akan berhasil tanpa adanya kurikulum pendidikan. Kurikulum pendidikan merupakan dasar komponen pokok dalam pendidikan. Salah satunya adanya prinsip-prinsip yang harus pegang dalam membuat kurikulum. Penyusunan kurikulum memiliki landasan yang kuat dan di- dasarkan atas pemikiran dan penelitianyang mendalam. Untuk penyusunan kurikulum juga mengikuti beberapa prinsip-prinsip tertentu yang akan menjadi bingkai agar tetap mengikuti tujuan kurikulum semula (Asmariani, 2016: 60). Berikut Prinsip Pengembangan Kurikulum secara umum, antara lain (Baharun, 2017: 195): 


\section{Prinsip Relevansi}

Kata relevansi atau relevan mempunyai arti (closely) connected with what is happening, yaitu adanya kedekatan hubungan dengan apa yang nantinya akan terjadi. Tertuang dalam Oxford Advanced Dictionary of Curren English. Ketika dikaitkan dengan dunia pendidikan, maka perlu singkronisasi antara (program) pendidikan dengan tuntutan kehidupan masyarakat (the needs of society). Pendidikan dikatakan relevan bila hasil yang diperoleh akan berguna bagi kehidupan masyarakat.

Ada dua jenis prinsip relevansi, yang pertama relevan eksternal (external relevance) yaitu kurikulum harus disesuaikan dengan tuntutan dan kebutuhan yang dimiliki oleh masyarakat, baik kebutuhan atau tuntutan masyarakat yang ada pada masa kini maupun prediksi kebutuhan pada masa yang akan datang. Kedua relevan internal (internal relevance) yaitu kesesuaian antara komponen kurikulum itu sendiri. Sehingga kurikulum merupakan suatu sistem yang dibangun oleh subsistem atau komponen, yaitu tujuan, isi, metode, dan evaluasi untuk mencapai tujuan tertentu, belajar dan kemampuan siswa.

\section{Prinsip Efektifitas}

Prinsip ini menunjukkan pada suatu pengertian bah- wa kerikulum selalu beriorentasi pada tujuan tertentu yang ingin dicapai. Kurikulum merupakan instrumen untuk mencapai tujuan. Oleh karena itu, jenis dan ka- rak teristik tujuan apa yang ingin dicapai harus jelas. Efektifitas dalam proses pendidikan dilihat dari dua sisi, diantaranya:

1. Efektifitas dalam mengajar pendidikan dimana erat kaitannya dengan bagaimana kegiatan belajar mengajar yang direncanakan dapat terlaksana dengan baik sehingga proses belajar mengajar lebih efektif.

2. Efektifitas belajar oleh anak didik, kaitannya dengan bagaimana tolak ukur kemampuan anak didik kan mencapai tujuan dalam pembelajaran sehingga apa yang diinginkan akan sesuai dengan 
harapan dengan melalui kegiatan belajar mengajar yang telah dilaksanakan.

Efektifitas dalam proses belajar mengajar di dunia pendidikan memiliki keterkaitan yang sangat erat antara pendidik dan peserta. Kepincangan salah satunya akan membuat ter- hambatnya pencapaian tujuan pendidikan, atau efektifitas belajar mengajar tidak tercapai. Faktor pendidik dan anak didik, serta perangkatperangkat lainnya yang bersifat operasional, sangat penting dalam hal efektifitas proses pendidikan atau pengembangan kurikulum.

\section{Prinsip Efisiensi}

Kurikulum mengarah pada prinsip praktis, yaitu dalam proses pembelajaran dapat memahami dan mudah implentasikan dilapangan. Krikulum diterapkan dalam praktik pendidikan (educational practice), sehingga apabila sudah keharusan maka paling tidak pembelajaran akan dilaksanakan sesuai situasi dan kondisi tertentu ketika dilapangan

Hal ini yang dikatakan bahwa usaha yang dilakukan itu efisien. Jadi akan menjadi efisiensi apabila menjukkan hasil yang seimbang dan itu merupakan perbandingan antara hasil yang dicapai dan pengeluaran yang diharapkan. Disisi lain prinsip juga memperhatikan tingkat ekonomis dan harus diterapkan dengan dukungan penuh oleh tenaga pendidik, juga waktu dan akan menggunakan biaya sedikit atau seminimal mungkin untuk memperolah hasil yang optimal (Asmariani, 2016: 61).

\section{Prinsip Kontinuitas}

Prinsip kontinuitas yaitu pengembangan kurikulum dilakukan secara berkesinambungan meliputi kontiunitas antarkelas maupun kontiunitas antar jenjang pendidikan. Maksud dari hal ini agar dalam proses pendidikan atau belajar siswa dapat maju secara berkesinambungan. Pendidikan pada kelas, jenjang yang sama atau tingkat bawah minimal harus menjadi dasar untuk dilanjutkan pada kelas dan jenjang di atasnya. Sehingga, akan terhindar dari tidak terpenuhinya pada kemampuan sebagai prasyarat awal siswa 88 
(prerequisite) untuk dapat mengikuti pendidikan di kelas atau jenjang pendidikan yang lebih tinggi, begitu juga akan terhindar dari adannya pengulangan program dan aktivitas belajar yang sesuai (negatively over laping), dimana juga bisa menimbulkan waktu yang banyak, tenaga, dan dana. Dengan demikian, perlu ada kerja sama antara pengembang kurikulum dari berbagai kelas dan jenjang pendidikan.

\section{Prinsip Fleksibilitas (Keluwesan).}

Fleksibilitas berarti tidak kaku artinya adanya semacam suatu ruang gerak yang dapat memberikan kebebasan dalam melakukan tindakan. Kurikulum yang baik adalah apabila kurikulum yang berisi dengan hal-hal yang kuat atau solid, tetapi dalam proses pelaksanaannya kemungkinan akan terjadi penyesuaiaanpenyesuaian terhadap kondisi daerah (Asmariani, 2016: 61). Fleksibiltas dalam kurikulum menjadi dua macam:

1. Fleksibilitas dalam memilih proram pendidikan. Fleksibilitas disini maksudnya adalah bentuk pengadaan program-program pilihan yang dapat ber bentuk jurusan, program spesialisasi, ataupun prog ram-program pendidikan keterampilan yang dapat dipilih anak didik atas dasar kemampuan dan mi natnya.

2. Fleksibilitas untuk pengembangan program pengajaran Fleksibilitas disini maksudnya adalah dalam bentuk memberikan kesempatan terhadap para pendidik untuk mengembangkan sendiri program-program pengajaran dengan mengarah pada tujuan dan bahan pengajaran yang sesuai didalam kurikulum dimana masih bersifat umum.

\section{Prinsip Beorientasi}

Pada Tujuan Prinsip beorientasi pada tujuan berarti bahwa sebelum bahan akan ditentukan, langkah pertaman yang perlu dilakukan oleh pendidik yaitu menentukan tujuan pembelajaran terlebih dahulu. Hal ini dilakukan agar supaya apa yang menjadi tujuan kita dalam meyampaikan semua materi menjadi sesuai dan semua jam dan aktivitas pengajaran yang dilaksanakan oleh 
pendidik maupun anak didik dapat betul-betul terarah kepada agar tercapainya tujuan pendidikan yang diharapkan. Dengan adanya kejelasan tujuan, pendidik diharapkan dapat menentukan secara tepat metode mengajar, alat pengajaran dan evaluasi.

\section{Pendidikan sepanjang hayat Pendidikan}

Pendidikan sepanjang hayat artinya pendidikan yang sesuai bagi orang-orang yang hidup dalam dunia transformasi, dan juga di dalam suatu masyarakat yang sama-sama saling mempengaruhi misalnya saat zaman globalisasi sekarang ini. Setiap manusia dituntut untuk menyesuaikan dirinya dengan perkembangan zaman dan secara terus.

\section{Prinsip Sinkronisasi}

Kurikulum harus dikembangkan dan disesuaikan agar supaya semua kegiatan kurikuler, ekstrakulrikuler dan kokurikuler serta pengalaman belajar lainnya dapat selaras, serasi, seimbang, searah dan setujuan. Hal juga perlu diperhatikan jangan sampai terjadi suatu kegiatan kurikuler yang menjadi menghambat, bertolakbelakang dan menurukan minat siswa dalam mengikuti kegiatan-kegiatan kurikuler lainnya termasuk kegiatan ekstra dan kokulikuler.

Dalam hal ini prinsip pengembangan kurikulum diharapkan sebagai tujuan perilaku untuk dapat mencintai lingkungan. Proses untuk memperoleh sebuah pengetahuan dan ketrampilan dibutuhkan sebuah wadah salah satunya adalah sekolah yang mengajarkan berbagai macam.

\section{Implikasi Kurikulum 2013}

Menurut Oemar Hamalik Kurikulum adalah suatu program pendidikan yang telah disediakan oleh lembaga pendidikan (sekolah) bagi siswa yang tidak terbatas pada sejumlah mata pembelajaran, namun meliputi semua yang berkaitan dengan perkembangan siswa dimana kurikulum diartikan sebagai semua kegiatan kursus yang diselenggarakan, dan juga pengalaman- 
pengalaman yang dimiliki oleh siswa di bawah derivasi sekolah baik di dalam maupun di luar kelas (Atiqoh, 2018: 291).

Dengan adanya perubahan kurikulum 2013 saat ini membawa dampak implikasi terhadapat sistem pembelajaran yang dilakukan. Ada empat hal yang mendasar dalam Implikasi perubahan kurikulum 2013 yaitu model pembelajaran berupa pendekatan saintifik, tematik integratif, strategi aktif, dan penilaian autentik (Machali, 2014: 88). Dari empat hal tersebut diantaranya yang pertama penerapan model pembelajaran tematik terpadu. Artinya penerapan pembelajaran tematik terpadu mengintegrasikan berbagai kompetensi dari berbagai mata pelajaran ke dalam berbagai tema. Kedua Pendekatan saintifik dalam pembelajaran memiliki tujuan untuk mengaktifkan agar efektif dalam menumbuhkan kratifitas belajar peserta didik. Ketiga strategi pembelajaran aktif dan kreatif yang mengarah dalam mmeberikan fasilititas yang penuh demi tercapainya semua kompetensi yang disusun sesuai rancangan dalam dokumen kurikulum, sehingga yang diharapkan pada setiap individu menjadi mandiri sepanjang, dan keempat adalah penilaian otentik. Dimana penilaian ini menjadi otentik atau autentik apabila adanya suatu proses penilaian yang dapat dipercaya, asli, nyata, valid, atau reliabel yang diperoleh dari hasil proses pembelajaran. Sedangkan maksud dari penilaian otentik berarti penilaian yang dilakukan melalui cara komprehensif artinya untuk mencapai proses penilaian melalui beberapa proses tahapan misalnya menilai mulai dari mengentri (input) nilai, proses dalam melakukan aktifitas di dalam kelas maupun diluar kelas, dan keluaran (output) pembelajaran yang merupakan dari hasil yang telah dicapai.

\section{Kurikulum 2013 berbasis Adiwiyata}

Lingkungan merupakan sesuatu yang ada di likungan sekitar kita, dalam kehidupan manusia yang kita sadari tidak akan pernah terlepas dari pengaruh lingkungan kita. Segala tuntutan yang menjadi kebutuhan hidup disekitar kita mendorong manusia untuk bisa beradaptasi dengan lingkungan melalui segala macam cara 
sesuai kemampuan manusia itu sendiri, bahkan dari dorongan ini semuanya tidak terbatas pada adaptasi lingkungan, melainkan menjadi motivasi untuk memberdayakannya dengan melakukan penyeimbangan ilmu pengetahuan dan teknologi (Astuti, 2015: 3).

Mata pelajaran yang diintegrasikan dengan adiwiyata memiliki tujuan masing-masing. Kompetensi inti dalam pelajaran Ilmu Pengetahuan Sosial adalah bagaimana bia menghargai dan menghayati cara berperilaku jujur, disiplin, tanggung jawab, santun, percaya diri, peduli (toleransi, gotong royong), dalam berinteraksi dengan lingkungan sekitar merupakan cara yang paling efektif untuk berinteraksi dengan lingkungan sosial dan alam dalam jangkaun pergaulan dan keberadaannya. Dari Kompetensi Inti diatas bisa dikatakan bahwa nantinya peserta didik mempunyai kepedulian terhadap lingkungan alam dan berinteraksi dengan alam secara arif. Jadi hal tersebut telah sesuai dengan Visi dan Misi sekolah yaitu mencetak generasi global, berjati diri lingkungan (Saliman, 2018: 12).

Untuk menciptakan proses pembelajaran yang bermutu dan menjadi berkualitas maka perlu lingkungan yang cukup kondusif sangat diperlukan di sekolah. Dalam mentransfer berbagai ilmu pengetahuan, perlu adanya pembentukan kesadaran siswa tentang bagaimana menjadikan perilaku hidup yang bersih dan sehat sehingga terasa sangat efektif. Pada saat berada di luar lingkungan sekolah, sebagai seorang siswa dan sadar akan lingkungan bersih dan sehat maka ia harus mampu menerapkan hidup bersih dan sehat seperti saat di sekolahnya.

Kita harus menyadari bahwa lingkungan dan budaya pendidikan sekolah merupakan diluar dari budaya pembelajaran yang menjadi faktor ekternal yang akan membangun budaya yang baik pula sehingga untuk menumbukan kesadaran tersebut perlu adanya kesadaran diluar sekolah dalam menciptkan lingkungan yang bersih dan sehat.

Lingkungan hidup disekolah kita jika dibangun dengan menciptkan suasana yang alami, islami dan ilmiah, maka yang akan membangun budaya jujur, ramah, kompak, cinta akan ilmu 
disebuah sekolah kemudian terciptanya proses proses transfer nilai, sikap, dan perbuatan yang telah dilakukan dengan tanpa sadar yang telah dilakukan peseta didik. Dan ini sangat berbeda dengan suatu perusahan yang memiliki standar operasional proserdur (SOP) yang jelas sehingga terciptanya suasanya dan budaya hidup bersih.

Ketika sekolah sudah menerapkan budaya lingkungan yang sehat dan bersih maka harapannya menjadi salah satu bentuk kesadaran dalam meningkatkan pengetahuan dan kemampuan yang dimiliki siswa sebagai peran penting dalam menyumbang perubahan yang terjadi dalam keluarga maupun di lingkungan sekitar. Untuk menghargai air bersih, memahami bagaimana pentingnya penghijauan dilingkungan sekitar, perlu memanfaatkan fasilitas sanitasi secara tepat dan mengelola sampah yang baik untuk menjadi pupuk tidak terpisahkan dalam upaya peningkatan kesadaran perilaku hidup bersih dan sehat. Salah satu hal terkecil dalam lingkungan masyarakat adanya perubahan yang terjadi dalam keluarga yang akan memberikan pengaruh positif terhadap lingkungan sekitar atau masyarakat.

Kegiatan lingkungan juga bersifat partisipasif dimana akan dilaksanakan sesuai standar sekolah Adiwiyata yang ditentukan oleh Kementrian Lingkungan Hidup dan Kementrian Pendidikan (Kemendikbud, 2011: 24). Sebuah buku Panduan tentang Adiwiyata ada beberapa standar kegiatan yang menjadi tolak ukur adiwiyta standar kegiatan yang pertama adalah kesadaran untuk memelihara dan merawat sarana dan gedung yang ada dilingkungan sekolah oleh warga sekolah, Kemudian standar yang kedua adalah pemanfaatan lahan yang baik dan penggunaan fasilitas sesuai dengan kaidah-kaidah lingkungan hidup melalui pembuatan kolam, pembuatan taman dan pengadaan alat pengkomposan. Kriteria yang ketiga adalah adanya kreatifitas dan inovasi warga sekolah dalam upaya perlindungan dan pengelolaan lingkungan hidup melalui: pembuatan pupuk kompos dan publikasi kerajinan siswa (Ssaliman, 2018: 15).

Penyelenggaraan aksi lingkungan tidak selalu dilakukan oleh sekolah itu sendiri, namun sekolah juga dapat mengikuti aksi 
lingkungan yang diselenggarakan oleh instansi luar. Sebagaimana dijelaskan dalam buku Panduan tentang Adiwiyata disbutkan bahwa salah satu standar dalam kegiatan lingkungan yang bersifat partisipasif ialah bagaimana cara mengikuti kegiatan dalam aksi lingkungan yang diselenggarakan oleh pihak luar (Kemendikbud, 2011: 24).

Dalam menerapkan materi adiwiyata / lingkungan hidup di sekolah perlu dilakukan dengan cara menyisipkan materi di dalam silabus yang terintegrasi melalui muatan kurikulum khusus mata pelajaran Muatan Lokal dan juga pembelajaran integral dengan pembelajaran yang lain baik mata pelajaran wajib maupun peminatan. Lingkungan juga dapat dijadikan media pembelajaran yang dikategorikan menjadi tiga macam, yakni lingkungan sosial, alam, dan lingkungan buatan (Baharun, 2017: 241). Model pembelajaran dikembangkan dalam materi, model dan metode belajar dibuat bervariasi dan dapat dilakukan dengan cara memberikan pemahaman yang penuh kepada siswa tentang bagaimana menjadikan lingkungan hidup yang sehat dan bersih jika dikaitkan dengan persoalan yang ada lingkungan kita.

Manajemen pengolahan lingkungan sekolah juga dapat dilakukan melalui beberapa cara yaitu meningkatkan ilmu pengetahuan dan kemampuan dasar siswa dalam penggunaan air yang secukupnya, sampah, penggunaan energi dan halaman yang ada disekitar sekolah, diantaranya:

\section{Pengelolaan air di sekolah}

Jika di sekolah sedang mengalami kekeringan atau kekurangan air bersih, mungkin kita akan membayangkan betapa pentingnya air untuk kita gunakan setiap hari, tentunya sekolah akan menjadi kotor karena tidak dibersihkan, kamar mandi akan mengeluarkan bau tidak nyaman yang akan menimbulkan penyakit dan membuat tidak nyaman sehingga lingkungan sekolah akan menjadi tidak sehat dan akan mengganggu kenyamanan dalam proses belajar mengajar. 
Ketersediaan kebutuhan air bersih sangatlah diperlukan dilingkungan sekolah sehingga penggunaan air cukup relatif banyak. Dengan adanya hal tersbut mengingat penggunaan air dilingkungan sekolah juga banyaknya jumlah pengguna di sekolah yakni guru, karyawan, siswa yang mencapai ratusan orang. Kemudian penggunaan kebutuhan air bersih akan menjadi lebih banyak lagi. Ada banyak berbagai jenis kebutuhan penggunaan air yang digunakan di sekolah untuk komsumsi sehari-hari seperti dibuat minum, wudhu', bemembersihkan lantai, menyiram tanaman, membersihkan kamar mandi, mencuci peralatan praktik laboratorium dan juga menyiram tanaman.

Pada zaman Teknologi saat ini, hampir semua kebutuhan hidup tidak lepas dari teknologi seperti pengolahan air limbah yang digunakan tentu sangat mahal harganya. Ada beberapa cara untuk mengatasi kekurangan penggunaan air bersih yaitu dengan cara bagaimana kita bisa menghemat penggunaan air, memakai seperlunya dan selalu menutup kran air ketika terlihat terbuka sehingga air tidak terbuang dengan sia-sia. Hal inilah perlu kita sadari dengan cara sering memberikan pemahaman dan menekankan pada saat pembelajaran baik di dalam mapun di luar jam kegiatan pembelajaran kepada seluruh warga sekolah khususnya kepada peserta didik.

\section{Penghematan energi di sekolah}

Sekolah sangat mementingkan dalam penggunaan energi seharihari, dimana digunakan agar dalam proses kegiatan pembelajaran dapat berjalan dengan kondusif. Pada saat penggunaan energi di sekolah, kebiasaan yang dilakukan adalah penggunaan media pembelajaran yang berbasis IT, meyalakan barang elektronik seperti komputer, speaker aktif, dan menghidup air ketika dibutuhkan dan lain-lain.

Di sekolah paling tidak kita semua bersama-sama bertanggung jawab untuk memelihara penggunaan barang yang menggunakan energi listrik dan ikut serta menghemat ketika pemakaiannya. Banyak cara yang dapat kita lakukan untuk bisa pengelolaan energi 
di sekolah, misalnya melalui penggunaan energi matahari untuk bisa menerangi ruang belajar di kelas jadi tidak perlu menggunkan lampu, menggunakan ventilasi dan tidak perlu menggunakan AC dan lain-lain. Penggunaan aliran listrik bisa dikurangi dengan pemakaian air yang secukupnya karena disaat pemakaian air langsung dialirkan kelistrik, menghidupkan lampu seperlunya dan selalu mematikan lampu dikala tidak digunakan dan juga mematikan barang - barang elektronik seperti komputer, televise, kipas angin, AC disaat tidak digunakan.

Pembiasaan untuk menghemat energi, bisa dengan cara mengintegrasikan materi menghemat energi di dalam kurikulum, keteladanan seorang guru maupun karyawan, adanya pengawasan dan menempelkan poster atau slogan yang berisi hemat energi di setiap tempat di lingkungan sekolah

\section{Pengelolaan halaman kosong}

Dalam pengelolaan lingkungan bersih dan sehat tidak hanya dilakukan di dalam kelas melainkan juga bisa di luar kelas, misalnya di halaman. Halaman sekolah disisi lain di kelola dan tata keindahannya, perlu juga lebih memperhatikan persyaratan dalam kesehatan. Dikatakan halaman sekolah yang kurang sehat apabila menimbulkan berbagai macam gejala penyakit kemudian dapat menimbulkan rasa yang tidak nyaman bagi seluruh semua warga sekolah.

Selain halaman sekolah, tentunya masih banyak lahan yang tidak digunakan di sekitar lingkungan sekolah. Lingkungan Lahan kosong tersebut dapat difungsikan sebagai media kteratif siswa untuk belajar menanam dan juga bisa sebagai tempat mengkompos sampah. Untuk penanaman lahan kosong memiliki tujuan utamanya yaitu sebagai media pembelajaran dilingkungan sekolah baik dalam mata pelajaran muatan lokal yang terintegrasi dengan mata pelajaran yang relevan. Untuk merawat halaman dilingkugan sekolah perlu dilakukan oleh setiap warga sekolah semisal oleh guru, karyawan, siswa dan penjaga sekolah. Semua itu dilakukan dengan menyapu halaman, memugut sampah, dan menyirami 
tanaman yang selalu dilakukan setiap hari baik sebelum masuk maupun pulang sekolah.

\section{Bank sampah}

Sampah yang kita pahami lebih cendrung adalah kita tidak terlalu memikirkan bagaimana penggunaan sampah yang kita hasilkan itu berupa organik atau non-organik dan tidak menutup kemungkinan kita tifak terlalu peduli akan kemana sampah itu larinya. di Indonesia kenyataanya, khususnya di sekolah begitu banyak sekali sampah-sampah yang dihasilkan setiap harinya misalnya, botol air mineral, plastik bungkus makanan kecil, kertas, daun yang berserakan, dan lain-lain, ketika sudah tidak dibersihkan sampah akan menggunung.

Sering kita memahami bahwa penggunaan sampah yang kita hasilkan identik anggapan negatif, Didirikannya Bank Sampah adalah bagaimana membalikkan sampah yang identik dengan image negatif menjadi image positif. Sering kita kenal bahwa sampah adalah benda yang kotor, sangat berpotensi menimbulkan penyakit atau virus, adanya sarang nyamuk, dan munculnya hal buruk lainnya. serta sampah juga menjadi barang yang harus ditekan produksinya.

Ketika mengingat adanya bank sampah terdengar sangat berbeda. Sehingga anggapan atau persepsi tentang adanya sampah akan sangat berbeda. Dari sistem pengelolaan sampah yang baik dengan infaq sampah. Dengan sistem ini, siswa akan mendapatkan banyak keuntungan. Dengan dibuatnya sistem ini dengan sistem lainnya adalah adanya mekanisme atau cara pengelolaan sampah dengan infaq sampah. Infaq sampah di Bank Sampah dengan cara menyetor sampah merupakan salah satu upaya merubah pola pikir atau mindset tentang sampah Sampah menjadi sesuatu yang memiliki nilai ekonomis. Dalam sistem pengelolaan sampah di bank sampah tertuang dalam peraturan Undang - Undang No 18 tahun 2008 yang berisi bahwa dalam penyelenggaraan pengelolaan sampah dan sejenisnya dengan cara pengurangan sampah, 
penanganan sampah, dan sistem pengelolaan sampah. Adapun mekanisme bank sampah, antara lain:

1. Pemilahan sampah (organik dan anorganik);

2. Penyerahan sampah ke bank sampah;

3. Penimbangan sampah;

4. Catatan; dari hasil penjualan sampah organik yang diserahkan dan dimasukan ke buku tabungan atau dibelanjakan untuk pembelian bibit atau perawatan tanaman;

5. Pengolahan sampah.

Agar supaya pengelolaan sampah organik maupun non organik perlu dikelola dengan baik dan mencapai tujuan yang diinginkan, maka ketika kegiatan pengelolaan sampah harus mengikuti cara yang baik dan benar. Sehingga dalam segi manfaat sampah organik lebih berpotensi menjadi komposting (pengomposan) dimana sampah yang mudah membusuk dapat juga diubah manjadi pupuk kompos yang ramah lingkungan untuk melestarikan fungsi kawasan sekolah.

Perlu diketahui, bahwa penggunaan dan pemanfaatan sampah anorganik dilakukan baik secara langsung maupun tidak langsung. Sehingga sampah dapat dimanfaatkan kembali secara langsung dan dapat menghasilkan, misalnya bisa dibuat kerajinan dengan bahan baku dasar dari barang bekas yang tidak digunakan, atau kertas daur ulang. Sedangkan secara tidak langsung pemanfaatan sampah, misalnya menjual kembali barang bekas seperti koran bekas, botol gelas dan botol air minum dalam kemasan, kertas, plastik, kaleng. Dari hasil penjualan sampah tersebut bisa digunakan untuk pembelian bibit tanaman.

Pengelolaan bank sampah dilingkungan sekolah yang dilakukan oleh siswa diharapkan sampah yang tidak digunakan dapat berkurang dan dirubah menjadi sesuatu yang memiliki harga jual. Selain itu, manfaat lain lingkungan akan menjadi bersih dan indah, siswa pun juga terhindar dari penyakit ataupun virus.

Melalui program bank sampah tersebut, siswa akan diberi pembekalan untuk mampu dapat mengolah sampah dengan baik dan benar dengan cara melakukan komposting dan dapat 
mengubah sampah menjadi kerajinan agar supaya harapan untuk bisa bermanfaat bagi dirinya maupun masyarakat.

Salah satu bukti bahwa kita sebagai warga yang baik yaitu ikut turut serta menjalankan kebijakan pemerintah yang sedang dicanangkan dalam mengimplementasikan Kurikulum 2013 yaitu untuk mempersiapkan manusia Indonesia agak memiliki kemampuan hidup sebagai pribadi dan warga negara yang beriman, produktif, kreatif, inovatif, dan efektif agar mampu memberikan kontribusi terhadap kehidupan bermasyarakat, berbangsa, bernegara, dan juga peradaban dunia. Kita bersama-sama harus mengawal dan memupuk penerapan implementasi Kurikulum 2013 menjadi tonggak awal kita menyambut Indonesia lebih maju.

Berdasarkan bunyi pasal 36 ayat 1 dijelaskan bahwa "Pengembangan kurikulum dapat dilakukan dengan mengacu pada standar Nasional pendidikan untuk mewujudkan tujuan pendidikan Nasional". Bunyi pasal tersebut juga didukung oleh Pasal 36 ayat 2 yang berbunyi "Kurikulum pada semua jenjang dan jenis pendidikan dikembangkan melalui prinsip diversifikasi sesuai dengan satuan pendidikan, potensi daerah, dan peserta didik". Berdasarkan bunyi pasal tersebut maka dalam pengembangan kurikulum di sekolah disesuaikan berdasarkan satuan pendidikan dan potensi daerah masing-masing sebagai wujud desentralisasi pendidikan. Kurikulum berbasis lingkungan tetap mengacu pada kurikulum pada umumnya dengan mengacu pada standar nasional pendidikan dan untuk pengembangan integrasinya dikembangkan sendiri oleh sekolah. (Nurhayati, 2015: 5).

Pengembangan kurikulum Berbasis Adiwiyata merupakan bentuk upaya untuk membangun lingkungan yang bersih dan sehat menuju terciptanya kesejahteraan, harapan ini dapat menjadi solusi atas problematika dilingkungan hidup sekitar kita pada umunya yang terjadi di Indonesia sehingga akan terwujud generasi peneruspenerus bangsa yang memiliki pemahamaham bagaimana berpikir positif dalam peduli lingkungan lingkungan, memiliki kesadaran, ilmu pengetahuan, keterampilan. 


\section{Catatan Akhir}

Pemanasan global dapat dicegah melalui pendidikan lingkungan hidup dengan mengubah perilaku yang buruk menjadi lebih bijaksana dalam mengelola lingkungan hidup dengan baik. Dalam memecahkan permasalahan lingkungan tersebut sangat dibutuhkan kehadiran model pendidikan lingkungan yang sejak dini dilakukan dimulai dari sekolah oleh guru yang berkompetensi. Pendidikan lingkungan di sekolah merupakan proses pembelajaran yang efektif melalui sistem penyampaian dengan pengintegrasian pada bidang studi yang diajarkan. Hal ini diyakini dapat mempengaruhi pelajar sebagai masyarakat atas nilai-nilai dan isu permasalahan lingkungan.

Pemerintah berencana untuk berhasil dalam mewujudkan apa yang dicita-citakan kurikulum 2013, yaitu untuk mempersiapkan orang Indonesia untuk memiliki kemampuan untuk hidup sebagai individu dan warga negara yang setia, produktif, kreatif, inovatif, dan efektif serta mampu berkontribusi untuk kehidupan dunia, bangsa, negara, dan peradaban dunia. Dengan "Pengembangan Kurikulum Berbasis Adiwiyata di Sekolah Menengah Kejuruan" dalam hal ini merupakan upaya untuk dapat menjadi jawaban atas masalah yang ada di lingkungan kita serta yang terjadi di Indonesia secara umum, sehingga ada akan menjadi generasi masa depan yang kompeten.

\section{Daftar Pustaka}

Afifah, Nurul 2017. 'Problematika Pendidikan di Indonesia (Telaah Dari Aspek Pembelajaran )', Elementary, 1, 41.

Asmariani. 2016 'Prinsip-Prinsip Pengembangan Kurikulum Dalam

Perspektif Islam', Al-Afkar: Jurnal Keislaman \& Peradaban, 2, 60.

Astuti 2015. Frismi, 'Implementasi Program Adiwiyata Dalam Pengelolaan Lingkungan Sekolah Dan', Edu Geography, 3, 3. Atiqoh, Layly, and Budiyono Saputro. 2018. Kurikulum Pendidikan Agama Islam Berbasis Lingkungan Sebagai Penguatan Pendidikan Humanistik Di Sekolah Adiwiyata, Edukasia: Jurnal Penelitian Pendidikan Islam, 12, 291. 
Baharun, Hasan. 2017. Konsep, Prinsip, Model, Pendekatan Dan Langkah-Langkah Kurikulum PAI. Yogyakarta: Pustaka Nurja.

- 2016. Pengembangan Media Pembelajaran PAI Berbasis Lingkungan Melalui Model Assure', Cendekia: Joumal of Education and Society, 14, 231-46.

Saliman, Fauzi Setyobudi. 2018. Pendidikan Lingkungan Hidup', JIPSINDO, 5, 15.

Fujiawati, Fuja Siti. 2016, Pemahaman Konsep Kurikulum Dan Pembelajaran Dengan Peta Konsep Bagi Mahasiswa Pendidikan Seni, Jurnal Pendidikan Dan Kajian Seni, 1, 16-28.

Kemendikbud. 2011. Sekolah Peduli Dan Berbudaya Lingkungan. Jakarta.

Machali, Imam. Kebijakan Perubahan Kurikulum 2013 Dalam Menyongsong Indonesia Emas Tahun 2045, Jurnal Pendidikan Islam, 3 (2014), $88<$ https://doi.org/10.14421/jpi.2014.31.7194.

Muali, Chusnul. 2017. Rasionalitas Konsepsi Budaya Nusantara dalam Menggagas Pendidikan Karakter Bangsa Multikultural, Jurnal Islam Nusantara, 1, 105-17.

Nurhayati, Ela. 2015. Implementasi Kurikulum Berbasis Lingkungan Di Sekolah Adiwiyata: Studi Kasus Si SMP Negeri 16 Surabaya, Jurnal Manajemen Pendidikan, 2, 5.

Wahid, Hamid. 2018. Rekonstruksi Pendidikan Islam Kontemporer dalam Perspektif Transformasi Sosial, HIKMAH: Jurnal Pendidikan Islam, 7, 1-21.

Purwantiningsih, Ary, Pudjo Suharso, and Aditia Ismaya. 2018. Melalui Peningkatan Profesionalisme Guru ( Belajar Dari Pengalaman Jepang ), Ilmiah Kependidikan, 9, 31.

RI, Kementrian. 2018. Undang-Undang No. 18, Tentang Pengelolaan Sampah.

Azis, Rosmiaty. 2016. Kerangka Dasar dalam Pengembangan Kurikulum 2013, Jurnal Keguruan Universitas Islam Negeri Alauddin Makassar, 5, 286-92. 